\title{
日本人摂取たん白質のアミノ酸組成とその栄養評価*
}

\author{
岩 谷昌子 \\ 国立栄養研究所 基礎栄養部
}

\section{Amino Acid Composition of Dietary Protein Ingested by the Japanese and its Nutritional Evaluation}

\author{
Masako Iwaya \\ Division of Basic Nutrition, National Institute of Nutrition
}

To evaluate nutritive value of dietary protein ingested by the Japanese during the last decade (1973 1982), daily intake of amino acids and value of amino acid score were calculated based on the data of the National Nutrition Survey, Japan. In addition, amino acid intake from individual food groups was calculated from 1982 data alone.

The results are shown as follows:

1) Mean dietary intake of amino acids per person between 1973 and 1982 ranged from 77.4 to $79.8 \mathrm{~g} /$ day, indicating only a small difference. Since the ratio of essential amino acids to total amino acids (EA\%) ranged between 42.5 and $42.7 \%$, nutritive value of the dietary protein was found to be satisfactorily high.

2) The values of amino acid score of the dietary protein ranged from 98 to 100 during the last decade (1973 1982), indicating also satisfactorily high nutritive value of the protein on the basis of chemical score.

3) The ratio of animal protein to total protein was $50.9 \%$ in 1982 . As for the amino acid intake individual food groups, several kinds of amino acids were found to be ingested from plant foods, especially cereals, rather than animal foods.

Jpn. J. Nutr., 42 ( 5 ) 297 304 (1984)

昭和 21 年の終戦直後から毎年厚生省が実施している国民栄養調查は, 日本人の摂取栄養素の実態および健康 状態を明らかにして，国民の栄養改善対策，さらに健康增進のための基礎資料を得るら壳で重要な調査である。 この国民栄養調査成績をもとにして，すでに松野らは昭和21年から昭和49年までの日本人の必須アミノ酸摂取 量を算出し，化学的評点法によりその摂取たん白質の質的評価を行った結果について報告している1) 3)。

しかし近年，必須アミノ酸ばかりでなく，アルギニン，プロリン，ヒスチジンなどの非必須アミノ酸につい ても，それらの栄養学的意義において注目されはじめている45)。そこで今回，昭和48年から最近公刊された 昭和57年までの過去 10 年間の国民栄養調查成績(6) から, 全国平均 1 人 1 日当たりの必須アミノ酸および非必須 アミノ酸摂取量を算出して, 摂取たん白質の質的評価をするため, アミノ酸パターンの年次变化掞よびアミノ 酸スコアについて比較検討を行った。

\footnotetext{
* : 摂取たん白質の栄養評価について (第 1 報)
}

Key words : nutritional evaluation, protein, amino acid, amino acid score 栄養評価, たん白質, アミノ酸, アミノ酸スコア 
表 1 食品類別たん白質・窒素

\begin{tabular}{|c|c|c|c|c|}
\hline No. & 国民栄養調査の食品類 & 日本食品アミノ酸組成表の対応食品 & $\begin{array}{l}\text { たん } \\
\text { 白質 }\end{array}$ & 窒素 \\
\hline 1 & 米 & 白 & 6.8 & 1.14 \\
\hline 2 & 大 麦 & 押乙＼cjkstart麦（大麦） & 8.6 & 1.48 \\
\hline 3 & 小麦粉, 乾めん・マカロ =, 即席めん & 小麦粉 3 種 (薄・中・強力粉) の平均 & 10.2 & 1.79 \\
\hline 4 & パン，菓子パン & 食 パ y & 8.0 & 1.40 \\
\hline 5 & 生めん・ゆでめん & う ぞ ん & 3.4 & 0.60 \\
\hline & その他の穀類 & そば粉, コーンフレーク, とうもろこしの平均 & 6.7 & 1.07 \\
\hline 7 & 種実類 & 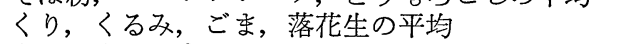 & 15.5 & 2.92 \\
\hline & さっまいも & さつまいも & 1.2 & 0.19 \\
\hline 9 & ごゃがいも，いも類加工品 & じゃがいも & 1.6 & 0.26 \\
\hline 10 & その他のいも & さ & 2.6 & 0.42 \\
\hline 11 & せんべい類, カステラ・ケーキ類, ビスケット類 & 精白米，小麦粉（薄力粉）の平均 & 5.9 & 0.94 \\
\hline 12 & その他の菓子類 & スイートチョコレート & 5.6 & 0.90 \\
\hline 13 & 味噌 & 甘味噃, 辛味噌, 豆味噌の平均 & 12.6 & 2.21 \\
\hline 14 & 豆腐, 豆腐加工品 & 豆腐 & 7.7 & 1.35 \\
\hline 15 . & 大豆・その他。 & 大豆, 凍豆腐, なっとう, おからの平均 & 16.6 & 2.91 \\
\hline 16 & その他の豆類 & あずき，いんげん豆など 5 種の平均 & 10.8 & 1.73 \\
\hline 17 & 柑 滳 類 & みかん，なつみかんの平均 & 0.8 & 0.13 \\
\hline 18 & ウ ん ご & り んご こ & 0.2 & 0.03 \\
\hline 19 & バ & ナ & 1.1 & 0.18 \\
\hline 20 & い ち ご & w & 0.9 & 0.14 \\
\hline 21 & その他の果実, 果汁 & かき,すいか，なし，ぶどう，ももの平均 & 0.3 & 0.05 \\
\hline 22 & にんじん & にんじん & 1.2 & 0.19 \\
\hline 23 & 泀うれん草 & 汪られん草 & 3.3 & 0.53 \\
\hline 24 & ピーマン, その他 & かぼちゃ & 1.7 & 0.27 \\
\hline 25 & 大 根 & 大 根 & 0.8 & 0.13 \\
\hline 26 & たまねぎ & たまねぎ & 1.0 & 0.16 \\
\hline 27 & 卜 $\checkmark \quad$ r & r $>\quad+$ & 0.7 & 0.11 \\
\hline 28 & キャベッ & キャベッ & 1.4 & 0.22 \\
\hline 29 & きゅうり & きゅう & 1.0 & 0.16 \\
\hline 30 & はくさい & はくさい & 1.1 & 0.18 \\
\hline 31 & その他の野菜 & なす，ねぎなど 9 種の平均 & 1.5 & 0.24 \\
\hline 32 & 葉類漬けもの & はくさい漬け & 1.5 & 0.24 \\
\hline 33 & たくあん・その他の漬けもの & たくあん漬け & 1.5 & 0.24 \\
\hline 34 & きのこ 類 & しいたけ，マッシュルーム，まつたけの平均 & 2.7 & 0.43 \\
\hline 35 & 海 草 類 & あさくさのり,こんぶ, ひごき, わかめの平均 & 10.0 & 1.60 \\
\hline 36 & 乙 $ょ \zeta ゆ$ & 乙上 5 为 & 7.5 & 1.20 \\
\hline 37 & マヨネーズ & 鶏 卵 $1 / 7$ 量 & 1.7 & 0.27 \\
\hline 38 & 日本 酒 & 清 酒 & 0.5 & 0.08 \\
\hline 39 & ビー - ル & ビ - ル ル & 0.4 & 0.06 \\
\hline 40 & その他の嗜好飲料 & ココア, 茶 (浸出液) の平均 & 2.1 & 0.34 \\
\hline 41 & 孪ぐ ろ 類 & まぐろ（赤身，脂身)，きわだまぐろの平均 & 26.3 & 4.21 \\
\hline 42 & たい・かれい類 』』～ & たい，ひらめ，かれい，たらの平均 & 18.1 & 2.90 \\
\hline 43 & 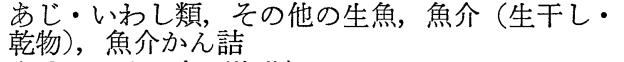 & あじ，いわし，さば，さんま，にしんの平均 & 23.8 & 3.81 \\
\hline 44 & さケ・ます，魚（塩蔵） & さけ，ます，にじますの平均 & 25.6 & 4.10 \\
\hline 45 & いか・たこ・かに & いか，たこ，かに，くるまえびの平均 & 16.5 & 2.64 \\
\hline 46 & 貝＼cjkstart類 & あさり, かき，はまぐり，ほたて貝の平均 & 25.8 & 4.13 \\
\hline 47 & 魚介佃 煮 & あみ，はぜ，ふなの平均 & 27.8 & 4. 45 \\
\hline 48 & 魚介 練 製 品 & かまぼこ，さつすあげ，ちくわ，はんぺんの平均 & 11.9 & 1.90 \\
\hline 49 & 魚肉ハム・ソーセージ & 魚肉ソーセージ & 11.9 & 1.90 \\
\hline 50 & 牛肉 & 牛肉 & 19.2 & 3.07 \\
\hline 51 & & 肉 & 17.0 & 2.72 \\
\hline 52 & & 肉 & 19.0 & 3.04 \\
\hline 53 & 鯨 肉 & 鯨 肉 & 23.0 & 3. 68 \\
\hline 54 & その他の肉 & うさぎ，馬肉，羊肉の平均 & 19.0 & 3.04 \\
\hline 55 & ハム・ソーセージ & ハム, ベーコン, ソーセージの平均 & 14.8 & 2.37 \\
\hline 56 & 卵＜wide>類 & 鶏 ～卵（全卵） & 12.3 & 1.97 \\
\hline 57 & 牛 & 乳 & 2.9 & 0.45 \\
\hline 58 & チ - ズ & チ - & 22.7 & 3.56 \\
\hline 59 & その他の乳製品 & 牛乳, 生クリームの平均 & 4.5 & 0.71 \\
\hline
\end{tabular}


荷重平均含量およびアミノ酸組成

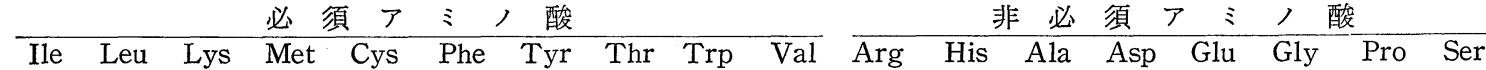

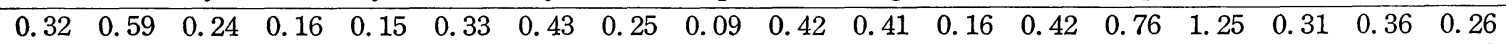

$\begin{array}{lllllllllllllllllll}0.25 & 0.52 & 0.23 & 0.12 & 0.19 & 0.41 & 0.47 & 0.24 & 0.09 & 0.34 & 0.25 & 0.13 & 0.27 & 0.37 & 1.91 & 0.27 & 0.93 & 0.28\end{array}$

$\begin{array}{llllllllllllllllll}0.41 & 0.74 & 0.24 & 0.16 & 0.19 & 0.48 & 0.32 & 0.28 & 0.12 & 0.46 & 0.41 & 0.19 & 0.25 & 0.45 & 3.26 & 0.37 & 1.29 & 0.50\end{array}$

$\begin{array}{llllllllllllllllll}0.32 & 0.57 & 0.18 & 0.11 & 0.16 & 0.40 & 0.32 & 0.24 & 0.10 & 0.38 & 0.25 & 0.18 & 0.25 & 0.40 & 3.24 & 0.29 & 0.99 & 0.40\end{array}$

$\begin{array}{llllllllllllllllll}0.11 & 0.19 & 0.07 & 0.04 & 0.05 & 0.12 & 0.08 & 0.07 & 0.03 & 0.12 & 0.12 & 0.06 & 0.06 & 0.12 & 0.83 & 0.10 & 0.33 & 0.12\end{array}$

$\begin{array}{llllllllllllllllll}0.29 & 0.79 & 0.30 & 0.13 & 0.14 & 0.36 & 0.14 & 0.27 & 0.08 & 0.39 & 0.52 & 0.19 & 0.48 & 0.61 & 1.43 & 0.33 & 0.63 & 0.37\end{array}$

$\begin{array}{llllllllllllllllll}0.70 & 1.18 & 0.60 & 0.22 & 0.16 & 0.86 & 0.62 & 0.61 & 0.23 & 0.86 & 2.00 & 0.42 & 0.82 & 1.65 & 3.36 & 0.98 & 0.89 & 0.87\end{array}$

$\begin{array}{llllllllllllllllll}0.05 & 0.08 & 0.05 & 0.01 & 0.02 & 0.05 & 0.06 & 0.06 & 0.02 & 0.07 & 0.04 & 0.02 & 0.07 & 0.21 & 0.17 & 0.05 & 0.04 & 0.06\end{array}$

$\begin{array}{llllllllllllllllll}0.08 & 0.12 & 0.11 & 0.02 & 0.02 & 0.07 & 0.05 & 0.08 & 0.03 & 0.12 & 0.11 & 0.04 & 0.08 & 0.26 & 0.35 & 0.07 & 0.08 & 0.07\end{array}$

$\begin{array}{lllllllllllllllllll}0.10 & 0.17 & 0.09 & 0.07 & 0.04 & 0.15 & 0.10 & 0.19 & 0.03 & 0.18 & 0.09 & 0.03 & 0.06 & 0.26 & 0.11 & 0.10 & 0.09 & 0.16\end{array}$

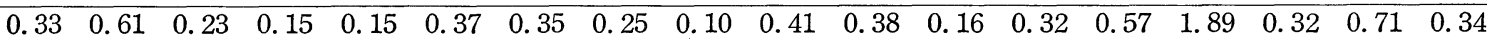

$\begin{array}{llllllllllllllllll}0.17 & 0.25 & 0.24 & 0.02 & 0.07 & 0.18 & 0.21 & 0.16 & 0.10 & 0.26 & 0.26 & 0.08 & 0.21 & 0.40 & 0.68 & 0.21 & 0.19 & 0.17\end{array}$

$\begin{array}{llllllllllllllllll}0.82 & 1.22 & 0.72 & 0.17 & 0.11 & 0.68 & 0.55 & 0.69 & 0.19 & 0.78 & 0.79 & 0.35 & 0.66 & 1.54 & 2.48 & 0.59 & 0.97 & 0.81\end{array}$

$\begin{array}{llllllllllllllllll}0.36 & 0.51 & 0.50 & 0.09 & 0.08 & 0.42 & 0.23 & 0.32 & 0.10 & 0.37 & 0.50 & 0.19 & 0.30 & 0.80 & 1.31 & 0.30 & 0.48 & 0.39\end{array}$

$\begin{array}{llllllllllllllllll}1.40 & 2.17 & 1.89 & 0.32 & 0.35 & 1.49 & 0.97 & 1.24 & 0.41 & 1.43 & 1.93 & 0.70 & 1.18 & 3.18 & 5.14 & 1.17 & 1.92 & 1.52\end{array}$

$\begin{array}{llllllllllllllllll}1.06 & 1.61 & 1.34 & 0.20 & 0.21 & 1.14 & 0.66 & 0.90 & 0.23 & 1.30 & 1.44 & 0.67 & 0.89 & 2.47 & 3.64 & 0.87 & 1.26 & 1.14\end{array}$

$\begin{array}{llllllllllllllllll}0.02 & 0.02 & 0.04 & 0.02 & 0.01 & 0.03 & 0.02 & 0.01 & 0.01 & 0.04 & 0.06 & 0.02 & 0.05 & 0.10 & 0.08 & 0.08 & 0.04 & 0.03\end{array}$

$\begin{array}{llllllllllllllllll}0.01 & 0.01 & 0.01 & 0.00 & 0.00 & 0.01 & 0.00 & 0.01 & 0.00 & 0.01 & 0.01 & 0.00 & 0.01 & 0.04 & 0.02 & 0.01 & 0.01 & 0.01\end{array}$

$\begin{array}{llllllllllllllllll}0.02 & 0.05 & 0.04 & 0.01 & 0.01 & 0.02 & 0.01 & 0.03 & 0.01 & 0.03 & 0.04 & 0.07 & 0.04 & 0.14 & 0.18 & 0.04 & 0.03 & 0.04\end{array}$

$\begin{array}{llllllllllllllllll}0.02 & 0.05 & 0.04 & 0.00 & 0.01 & 0.03 & 0.03 & 0.03 & 0.01 & 0.02 & 0.01 & 0.01 & 0.04 & 0.20 & 0.13 & 0.04 & 0.04 & 0.03\end{array}$

$\begin{array}{llllllllllllllllll}0.01 & 0.02 & 0.03 & 0.01 & 0.01 & 0.01 & 0.01 & 0.02 & 0.00 & 0.01 & 0.02 & 0.01 & 0.01 & 0.07 & 0.08 & 0.01 & 0.02 & 0.02\end{array}$

$\begin{array}{llllllllllllllllll}0.02 & 0.04 & 0.04 & 0.01 & 0.01 & 0.02 & 0.02 & 0.03 & 0.01 & 0.04 & 0.06 & 0.02 & 0.05 & 0.15 & 0.27 & 0.03 & 0.03 & 0.03\end{array}$

$\begin{array}{lllllllllllllllllll}0.10 & 0.20 & 0.17 & 0.02 & 0.01 & 0.13 & 0.11 & 0.12 & 0.04 & 0.13 & 0.17 & 0.06 & 0.15 & 0.33 & 0.53 & 0.14 & 0.12 & 0.11\end{array}$

$\begin{array}{llllllllllllllllll}0.04 & 0.07 & 0.05 & 0.01 & 0.01 & 0.04 & 0.05 & 0.03 & 0.02 & 0.05 & 0.09 & 0.02 & 0.04 & 0.13 & 0.23 & 0.04 & 0.03 & 0.06\end{array}$

$\begin{array}{llllllllllllllllll}0.02 & 0.03 & 0.03 & 0.01 & 0.01 & 0.03 & 0.01 & 0.02 & 0.00 & 0.03 & 0.02 & 0.01 & 0.03 & 0.06 & 0.19 & 0.02 & 0.02 & 0.02\end{array}$

$\begin{array}{llllllllllllllllll}0.03 & 0.03 & 0.03 & 0.00 & 0.02 & 0.02 & 0.02 & 0.01 & 0.01 & 0.03 & 0.08 & 0.01 & 0.03 & 0.04 & 0.15 & 0.05 & 0.03 & 0.03\end{array}$

$\begin{array}{llllllllllllllllll}0.01 & 0.02 & 0.02 & 0.00 & 0.00 & 0.02 & 0.02 & 0.01 & 0.00 & 0.01 & 0.01 & 0.01 & 0.02 & 0.09 & 0.34 & 0.01 & 0.01 & 0.01\end{array}$

$\begin{array}{llllllllllllllllll}0.04 & 0.06 & 0.06 & 0.02 & 0.01 & 0.04 & 0.03 & 0.05 & 0.01 & 0.05 & 0.05 & 0.02 & 0.06 & 0.15 & 0.36 & 0.04 & 0.04 & 0.06\end{array}$

$\begin{array}{llllllllllllllllll}0.04 & 0.06 & 0.05 & 0.01 & 0.00 & 0.04 & 0.03 & 0.04 & 0.01 & 0.05 & 0.04 & 0.02 & 0.04 & 0.08 & 0.22 & 0.04 & 0.03 & 0.04\end{array}$

$\begin{array}{llllllllllllllllll}0.03 & 0.04 & 0.04 & 0.01 & 0.01 & 0.02 & 0.02 & 0.04 & 0.01 & 0.05 & 0.04 & 0.01 & 0.06 & 0.08 & 0.26 & 0.03 & 0.02 & 0.04\end{array}$

$\begin{array}{llllllllllllllllll}0.13 & 0.20 & 0.19 & 0.03 & 0.04 & 0.11 & 0.20 & 0.10 & 0.03 & 0.17 & 0.20 & 0.05 & 0.10 & 0.39 & 0.45 & 0.11 & 0.13 & 0.12\end{array}$

$\begin{array}{llllllllllllllllll}0.05 & 0.04 & 0.06 & 0.01 & 0.02 & 0.05 & 0.01 & 0.02 & 0.00 & 0.04 & 0.04 & 0.02 & 0.11 & 0.11 & 0.29 & 0.06 & 0.08 & 0.05\end{array}$

$\begin{array}{llllllllllllllllll}0.04 & 0.05 & 0.03 & 0.01 & 0.00 & 0.03 & 0.02 & 0.04 & 0.01 & 0.04 & 0.04 & 0.01 & 0.06 & 0.04 & 0.40 & 0.07 & 0.05 & 0.03\end{array}$

$\begin{array}{llllllllllllllllll}0.07 & 0.16 & 0.09 & 0.03 & 0.03 & 0.08 & 0.05 & 0.10 & 0.02 & 0.09 & 0.14 & 0.04 & 0.12 & 0.17 & 0.35 & 0.08 & 0.12 & 0.09\end{array}$

$\begin{array}{llllllllllllllllll}0.66 & 1.15 & 0.42 & 0.47 & 0.21 & 0.80 & 0.41 & 0.51 & 0.18 & 1.40 & 0.82 & 0.16 & 1.32 & 1.39 & 1.78 & 0.94 & 0.72 & 0.66\end{array}$

$\begin{array}{llllllllllllllllll}0.32 & 0.52 & 0.42 & 0.06 & 0.07 & 0.25 & 0.08 & 0.23 & 0.04 & 0.35 & 0.13 & 0.06 & 0.35 & 0.58 & 1.44 & 0.24 & 0.62 & 0.49\end{array}$

$\begin{array}{llllllllllllllllll}0.09 & 0.15 & 0.12 & 0.06 & 0.05 & 0.09 & 0.07 & 0.08 & 0.03 & 0.12 & 0.11 & 0.04 & 0.10 & 0.16 & 0.22 & 0.06 & 0.07 & 0.13\end{array}$

$\begin{array}{llllllllllllllllll}0.01 & 0.01 & 0.01 & 0.00 & 0.00 & 0.01 & 0.02 & 0.01 & 0.00 & 0.01 & 0.02 & 0.01 & 0.02 & 0.02 & 0.03 & 0.01 & 0.01 & 0.01\end{array}$

$\begin{array}{llllllllllllllllll}0.01 & 0.01 & 0.01 & 0.00 & 0.00 & 0.01 & 0.02 & 0.01 & 0.01 & 0.01 & 0.01 & 0.01 & 0.02 & 0.02 & 0.05 & 0.01 & 0.05 & 0.01\end{array}$

$\begin{array}{lllllllllllllllllll}0.29 & 0.43 & 0.41 & 0.03 & 0.13 & 0.30 & 0.37 & 0.27 & 0.17 & 0.44 & 0.44 & 0.14 & 0.37 & 0.68 & 1.17 & 0.37 & 0.34 & 0.29\end{array}$

$\begin{array}{llllllllllllllllll}1.26 & 2.21 & 2.34 & 0.64 & 0.31 & 1.11 & 1.13 & 1.16 & 0.34 & 1.43 & 1.38 & 1.10 & 1.54 & 2.92 & 3.66 & 1.05 & 0.95 & 1.02\end{array}$

$\begin{array}{lllllllllllllllllll}0.91 & 1.52 & 1.79 & 0.46 & 0.13 & 0.73 & 0.67 & 0.84 & 0.24 & 1.00 & 1.14 & 0.47 & 1.11 & 1.97 & 2.99 & 0.83 & 0.62 & 0.77\end{array}$

$\begin{array}{llllllllllllllllll}0.90 & 1.46 & 1.69 & 0.52 & 0.23 & 0.53 & 0.47 & 0.87 & 0.25 & 1.02 & 1.07 & 0.80 & 1.16 & 1.91 & 2.71 & 0.92 & 0.70 & 0.72\end{array}$

$\begin{array}{llllllllllllllllll}0.95 & 1.46 & 1.86 & 0.55 & 0.21 & 0.78 & 0.64 & 0.91 & 0.25 & 1.11 & 1.18 & 0.63 & 1.30 & 1.88 & 2.76 & 1.22 & 0.83 & 0.81\end{array}$

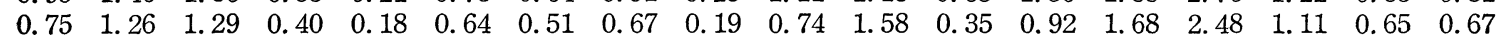
$\begin{array}{llllllllllllllllll}0.53 & 0.90 & 0.80 & 0.29 & 0.18 & 0.48 & 0.45 & 0.49 & 0.13 & 0.59 & 0.70 & 0.19 & 0.58 & 1.17 & 1.77 & 0.64 & 0.50 & 0.47\end{array}$ $\begin{array}{lllllllllllllllllll}0.77 & 1.46 & 1.59 & 0.55 & 0.20 & 0.74 & 0.62 & 0.74 & 0.19 & 1.98 & 0.91 & 0.37 & 1.96 & 1.93 & 2.40 & 0.82 & 0.57 & 0.72\end{array}$ $\begin{array}{llllllllllllllllll}0.55 & 0.90 & 0.93 & 0.32 & 0.11 & 0.45 & 0.42 & 0.53 & 0.11 & 0.51 & 0.68 & 0.28 & 0.66 & 1.26 & 2.00 & 0.55 & 0.43 & 0.47\end{array}$ $\begin{array}{llllllllllllllllll}0.46 & 1.90 & 0.90 & 0.24 & 0.14 & 0.46 & 0.39 & 0.53 & 0.12 & 0.52 & 0.72 & 0.33 & 0.72 & 1.07 & 2.02 & 0.77 & 0.59 & 0.50\end{array}$ $\begin{array}{llllllllllllllllll}0.98 & 1.79 & 1.86 & 0.46 & 0.24 & 0.91 & 0.72 & 0.91 & 0.26 & 1.11 & 1.27 & 0.72 & 1.30 & 1.89 & 3.59 & 0.91 & 0.85 & 0.68\end{array}$

$\begin{array}{llllllllllllllllll}1.04 & 1.73 & 1.89 & 0.55 & 0.24 & 0.85 & 0.72 & 0.91 & 0.29 & 1.11 & 1.24 & 0.85 & 1.21 & 1.96 & 3.00 & 0.91 & 0.78 & 0.72\end{array}$

$\begin{array}{lllllllllllllllllll}1.09 & 1.47 & 1.86 & 0.61 & 0.26 & 0.77 & 0.64 & 0.90 & 0.25 & 1.09 & 1.22 & 0.54 & 1.12 & 1.89 & 3.20 & 0.83 & 0.93 & 0.99\end{array}$ $\begin{array}{lllllllllllllllllll}1.10 & 2.06 & 2.10 & 0.44 & 0.29 & 0.96 & 0.74 & 0.96 & 0.32 & 1.14 & 1.40 & 0.96 & 1.36 & 1.77 & 3.50 & 0.92 & 0.96 & 0.88\end{array}$ $\begin{array}{llllllllllllllllll}0.96 & 1.28 & 1.79 & 0.54 & 0.24 & 0.71 & 0.64 & 0.88 & 0.26 & 1.06 & 1.33 & 0.57 & 1.13 & 1.75 & 3.09 & 0.90 & 0.80 & 0.96\end{array}$ $\begin{array}{llllllllllllllllll}0.57 & 1.01 & 1.07 & 0.35 & 0.15 & 0.50 & 0.48 & 0.58 & 0.16 & 0.63 & 0.92 & 0.44 & 0.84 & 1.23 & 2.28 & 0.89 & 0.78 & 0.55\end{array}$ $\begin{array}{llllllllllllllllll}0.65 & 1.04 & 0.87 & 0.41 & 0.33 & 0.63 & 0.47 & 0.57 & 0.20 & 0.81 & 0.79 & 0.31 & 0.69 & 1.12 & 1.55 & 0.39 & 0.49 & 0.89\end{array}$ $\begin{array}{lllllllllllllllllll}0.15 & 0.27 & 0.22 & 0.07 & 0.02 & 0.13 & 0.16 & 0.12 & 0.04 & 0.19 & 0.08 & 0.07 & 0.10 & 0.24 & 0.64 & 0.05 & 0.27 & 0.15\end{array}$ $\begin{array}{llllllllllllllllll}1.07 & 1.96 & 2.14 & 0.68 & 0.12 & 1.21 & 1.25 & 0.57 & 0.32 & 1.35 & 0.96 & 0.85 & 0.50 & 1.07 & 3.49 & 0.36 & 1.99 & 0.82\end{array}$ $\begin{array}{llllllllllllllllllll}0.14 & 0.27 & 0.21 & 0.06 & 0.03 & 0.13 & 0.14 & 0.12 & 0.04 & 0.17 & 0.09 & 0.07 & 0.09 & 0.21 & 0.51 & 0.05 & 0.23 & 0.14\end{array}$ 
方法

\section{1. たん白質，㕵素およびアミノ酸摂取量の算出方法}

国民栄養調査成績の食品群別掑取量から，たん白質量，窒素量およびアミノ酸量を算出するには，表 1 に示 すように，国民栄養調査で分類している89食品類に対応させた59の食品類別たん白質含量，およびアミノ酸組 成を作成して適用した。食品類別たん白質含量は，昭和57年国民栄養調查の「食品類別たん白質荷重平均成分 表」の数値から算出した。なお，昭和 57 年国民栄養調査成績から新しい「四訂日本食品標準成分表 (1982)」 (以下，四訂成分表 $)^{7)}$ とって集計が行われている。食品類別アミノ酸組成の作成は，「日本食品アミノ酸組 成表 (1966)」」多使用した。

また，国民栄養調査における食品群の中の “加工食品”および“その他の食品”については，使用されてい る原材料の種類やその配合割合がまちょちであること，日本食品アミノ酸組成表の中にそれらの対応食品がな いこと，これら食品群からのたん白質摂取量は，全体量の $1 \%$ 以内であること，などの理由により本研究の集 計には含めずに行った。

\section{2. アミノ酸スコアの算出方法}

表 2 に示すように, 1973 年に $\mathrm{FAO} / \mathrm{WHO}$ 合同 専門委員会より提案された必須アミノ酸基準パター ン9)をもとに，各年次の恸取たん白質の必須アミ， 酸パターンについて割合を算出し, その最低值（第 1 制限アミノ酸)をアミノ酸スコフとした。

なお，1981年10月，ローマ市で開催された FAO/ $\mathrm{WHO} / \mathrm{UNU}$ 合同専門委員会において, 新しいアミ ノ酸基準パターン10)が提案されているが，報告書が 未だ公刊されていないため今回は用いなかった。

\section{結果および考察}

表 2 アミノ酸基準パターン

\begin{tabular}{lc}
\hline アミノ酸 & 窒素 $(\mathrm{mg} / \mathrm{g})$ \\
\hline Ile & 250 \\
Leu & 440 \\
Lys & 340 \\
Met+Cys & 220 \\
Phe+Tyr & 380 \\
Thr & 250 \\
Trp & 60 \\
Val & 310 \\
\hline 合計 & 2,250 \\
\hline
\end{tabular}

資料) FAO/WHO (1973)

\section{1. 年次別たん白質およびアミノ酸摂取量}

表 3 亿新しい四訂成分表で算出したたん白質摂取量, 動物性たん白質比（動たん比）㘧よびアミノ酸摂取量 について，過去10年間の年次変化を示した。これらの值を三訂成分表によって集計した昭和48年，49年，56年 の值 ${ }^{11)}$ と比較すると，それぞれ近似した值でたん白質に関しては三訂成分表，四訂成分表のいずれを用いても 大差ないことがわかった。

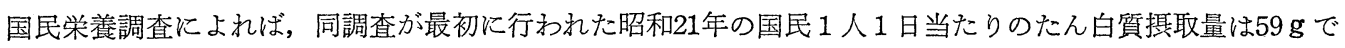
あり，その後は年々増加がみられ，昭和 30 年には $70 \mathrm{~g} ，$ 昭和 41 年には $75 \mathrm{~g} ，$ 昭和 47 年には $83 \mathrm{~g}$ にで増加した。 一方, 動たん比は, 昭和 21 年から 26 年までは18〜28\%とかなり低い割合を示し, その後は徐々に増加して, 昭 和39年までは30\%台であったが，昭和40年にはついに $40 \%$ ，昭和 47 年には49\%にまで上昇した。このように， たん白質摄取に抢いては他の栄養素と同様, 終戦後の極端な食料不足からその後の経済復興により食料事情の. 好転, 㘯るいは栄養教育, 栄養指導の普及などにより, 質および量ともに急速な改善がみられた。

昭和48年から現在までのたん白質摂取量の推移をみると（表 3 ), 昭和 48 年が $82.9 \mathrm{~g}$ と最高の摂取量となり, 49年以降現在までは多少の増減はあるにしろ, 78〜80 g の範囲内で横ばいの状態であった。動たん比は, 昭和 
表 3 年次別たん白質およびアミノ酸摂取量

(1人 1 日当たり；g)

\begin{tabular}{|c|c|c|c|c|c|c|c|c|c|c|c|}
\hline & 年次 (昭和) & 48年 & 49年 & 50 年 & 51年 & 52 年 & 53年 & 54年 & 55年 & 56年 & 57年 \\
\hline \multirow{2}{*}{\multicolumn{2}{|c|}{$\begin{array}{l}\text { たん白質㠌取量 } \\
\text { 動たん比（\%) }\end{array}$}} & 82.9 & 79.2 & 80.4 & 78.9 & 79.0 & 80.2 & 79.0 & 77.9 & 78.9 & 78.8 \\
\hline & & 48.8 & 47.7 & 48.7 & 48.3 & 49.1 & 49.7 & 50.2 & 50.6 & 51.1 & 50.9 \\
\hline \multirow{9}{*}{$\begin{array}{l}\text { 必貝 } \\
\text { ミ } \\
\text { 酸 }\end{array}$} & Ile & 3.87 & 3.74 & 3.79 & 3.72 & 3.73 & 3.80 & 3. 74 & 3.66 & 3. 70 & 3.73 \\
\hline & Leu & 6.45 & 6.21 & 6.29 & 6.18 & 6.19 & 6.30 & 6.20 & 6.08 & 6.14 & 6.19 \\
\hline & Lys & 5.12 & 4.93 & 5.03 & 4.92 & 4.96 & 5.08 & 5.01 & 4.91 & 4.98 & 5.01 \\
\hline & Met+Cys & 3.05 & 2.92 & 2.96 & 2.90 & 2.90 & 2.95 & 2.91 & 2.85 & 2.88 & 2.89 \\
\hline & Phe+Tyr & 7.17 & 6.91 & 6.99 & 6.86 & 6.86 & 6.99 & 6.86 & 6.70 & 6.75 & 6.82 \\
\hline & Thr & 3.34 & 3.22 & 3.27 & 3.21 & 3.21 & 3.28 & 3.23 & 3.16 & 3.18 & 3.21 \\
\hline & $\operatorname{Trp}$ & 1.10 & 1.06 & 1.08 & 1.05 & 1.06 & 1.08 & 1.06 & 1.02 & 1.03 & 1.05 \\
\hline & Val & 4.63 & 4.48 & 4.54 & 4.45 & 4.45 & 4.54 & 4.47 & 4.36 & 4.38 & 4.43 \\
\hline & 合 計 & 34.71 & 33.46 & 33.93 & 33.29 & 33.36 & 34.02 & 33.48 & 32.74 & 33.03 & 33.33 \\
\hline \multirow{9}{*}{ 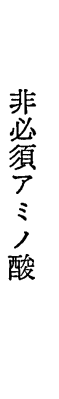 } & Arg & 4.78 & 4.57 & 4.64 & 4.53 & 4.54 & 4.63 & 4.54 & 4.43 & 4.47 & 4.50 \\
\hline & $\mathrm{His}$ & 2.23 & 2.12 & 2.16 & 2.11 & 2.12 & 2.17 & 2.13 & 2.09 & 2.11 & 2.12 \\
\hline & Ala & 4.44 & 4.24 & 4.30 & 4.20 & 4.20 & 4.28 & 4.20 & 4. 11 & 4.14 & 4.16 \\
\hline & Asp & 8.14 & 7.82 & 7.92 & 7.76 & 7.77 & 7.92 & 7.76 & 7.59 & 7.64 & 7.70 \\
\hline & Glu & 15.30 & 14.73 & 14.87 & 14.66 & 14.72 & 14.99 & 14.77 & 14.44 & 14.61 & 14.75 \\
\hline & Gly & 3.66 & 3.48 & 3.53 & 3.44 & 3.44 & 3.51 & 3.44 & 3.35 & 3.38 & 3. 40 \\
\hline & Pro & 4.65 & 4.49 & 4.54 & 4.48 & 4.49 & 4.57 & 4.51 & 4.41 & 4.46 & 4.52 \\
\hline & Ser & 3.73 & 3.62 & 3.66 & 3.60 & 3.61 & 3.68 & 3.63 & 3.53 & 3.57 & 3.61 \\
\hline & 合計 & 46.92 & 45.09 & 45.62 & 44.79 & 44.89 & 45.74 & 44.99 & 43.95 & 44.37 & 44.76 \\
\hline \multicolumn{2}{|c|}{ アミノ酸合計 } & 81.63 & 78.55 & 79.55 & 78.08 & 78.25 & 79.76 & 78.47 & 76.69 & 77.40 & 78.09 \\
\hline \multicolumn{2}{|c|}{$\mathrm{EA} \%$} & 42.5 & 42.6 & 42.7 & 42.6 & 42.6 & 42.7 & 42.7 & 42.7 & 42.7 & 42.7 \\
\hline
\end{tabular}

表 4 年次別摂取たん白質のアミノ酸パターンおよびアミノ酸スコア

$(\mathrm{mg} / \mathrm{Ng})$

年次 (昭和) 48 年 49 年 50 年 51 年 52 年 53 年 54 年 55 年 56 年 57 年 $\quad 10$ 年間 平均/基準 の平均 パターン

\begin{tabular}{|c|c|c|c|c|c|c|c|c|c|c|c|c|}
\hline Ile & 284 & 289 & 287 & 287 & 288 & 289 & 289 & 286 & 286 & 289 & 287 & 1.14 \\
\hline Leu & 474 & 478 & 477 & 477 & 478 & 479 & 479 & 476 & 474 & 479 & 477 & 1.08 \\
\hline Lys & 377 & 379 & 381 & 380 & 383 & 386 & 387 & 385 & 385 & 388 & 383 & 1.13 \\
\hline Met+Cys & 225 & 224 & 224 & 224 & 224 & 224 & 225 & 223 & 222 & 223 & 224 & 1.02 \\
\hline Phe+Tyr & 527 & 532 & 530 & 530 & 530 & 531 & 530 & 524 & 521 & 528 & 528 & 1.39 \\
\hline Thr & 246 & 248 & 248 & 248 & 248 & 249 & 249 & 247 & 246 & 249 & 248 & 0.99 \\
\hline $\operatorname{Trp}$ & 81 & 82 & 82 & 81 & 81 & 82 & 82 & 80 & 80 & 81 & 81 & 1.35 \\
\hline Val & 340 & 344 & 344 & 344 & 344 & 345 & 345 & 341 & 339 & 343 & 343 & 1.11 \\
\hline 合計 & 2,554 & 2,576 & 2,5732 & 2,571 & 2,5762 & 2,585 & 2,586 & 2,562 & 2,553 & 2,580 & 2,565 & \\
\hline $\begin{array}{l}\text { アミノ酸スコア** } \\
\text { (制限ミ酸) }\end{array}$ & $\begin{array}{c}98 \\
(\mathrm{Thr})\end{array}$ & $\begin{array}{c}99 \\
(\mathrm{Thr})\end{array}$ & $\begin{array}{c}99 \\
(\mathrm{Thr})\end{array}$ & $\begin{array}{c}99 \\
(\mathrm{Thr})\end{array}$ & $\begin{array}{c}99 \\
(\mathrm{Thr})\end{array}$ & 100 & 100 & $\begin{array}{c}99 \\
(\mathrm{Thr})\end{array}$ & $\begin{aligned} & 98 \\
\text { ) } & \mathrm{Thr}\end{aligned}$ & $\begin{array}{c}99 \\
\text { r) }(\mathrm{Thr})\end{array}$ & & \\
\hline
\end{tabular}

*:アミノ酸基準パターン $(\mathrm{FAO} / \mathrm{WHO}, 1973)$ より算出した值 
51年以降年々わずかずつ上昇していたが，昭和56，57年にはほぼ等值の51\%を示した。動たん比の望ましい割 合については，「日本人の栄養所要量（昭和 54 年改定)」吕の中で，〈成長期の場合 $45 \%$ ，成人期 $40 \%$ を目標とす るのが実用的である〉と解説されている。これよりみると，現在の日本人の動たん比 $51 \%$ はかなり高い割合 になっている。しかしながら，これらの上昇は青少年の体位向上やストレス，疾病に対する抵抗性などの健康 増進に役立っているものと思われる。

次に，昭和48年からのアミノ酸摂取量については，年次によって個々のアミノ酸量执よびその合計量に多少 の変動がみられた。これらの変動は，各年次におけるたん白質撕取量の違いによるものと考学られる。また， 食品たん白質の栄養価判定上重要とされる全アミノ酸に対する全必須アミノ酸割合 (EA\%) ${ }^{13)}$ 算出すると, この10年間を通して42.5〜42.7\%とほとえど同じ範囲にあった。各種食品について日本食品アミノ酸組成表 ${ }^{8}$

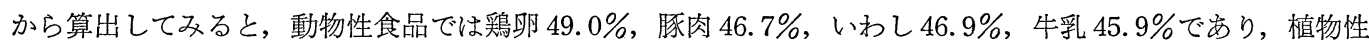
食品では白米 $43.1 \%$, 小麦粉（薄, 中, 強力粉平均) $33.7 \%$, 大豆 $41.6 \%$ であった。また松野ら ${ }^{13}$ によれば, 動物性食品の平均 $\mathrm{EA} \%$ は $45 \%$ であり, 植物性食品は $37 \%$ と報告している。日本人の過去 10 年間の平均が 42.7 \%ということは，植物性食品よりもわずかに動物性に近い值であり，全アミノ酸に占める必須アミノ酸摂取は， 概ね良好であることを示している。

\section{2. 年次別摃取たん白質のアミノ酸パターンおよびアミノ酸スコア}

摂取たん白質の必須アミノ酸パターン，およびアミノ酸スコアを表 4 に示した。必須アミノ酸摂取量を窒素 当たりで示しても，過去10年間は活とんど変化がみられなかった。10年間の平均值をアミノ酸基準パターンと 比較すると，スレオニンと含硫アミノ酸 (Met+Cys) は約1.0倍となり, 芳香族アミノ酸 (Phe+Tyr) とト リプトファンはおよそ 1.4 倍, その他のアミノ酸は 1.1 倍の值であった。これよりスレオニンと含硫アミノ酸 は，摂取食品によって，あるいは食物摂取量の減少によって制限アミノ酸となる可能性があることを示唆して いる。

各年次のアミノ酸スコアは，昭和48年が $98 ， 49 \sim 52$ 年が99，53〜 54年が $100 ， 55$ 年が $99 ， 56$ 年が $98 ， 57$ 年が 99 となった。アミノ酸スコアが100以下の制限アミノ酸は，いずれもスレオニンであった。昭和 48 年および 49 年の值については，松野らが報告したものとよく一致していた2)3)。

過去10年間の全国平均摂取たん白質の栄養価は，化学的評点法であるアミノ酸スコアからも良好な結果を得 た。なお，今後は諸種の階層別による検討が必要であると考觉る。

\section{3. 食品群別アミノ酸摄取量}

食品群別アミノ酸摂取量について, 最近の調查である昭和57年のみを表 5 に示し, 検討を行った。必須アミ ノ酸では,イソロイシンおよびロイシンについてみると，各食品群からの摂取量そのものはどれもロイシンの

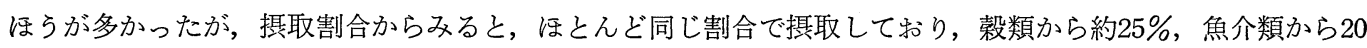
\%で，植物性食品と動物性食品の摄取割合はほぼ半々であった。リジンは，動物性食品からの摂取が多く，植 物性食品の 1.8 倍にも及んでいた。るた, 動物性食品の中では, 魚介類と肉類からの摂取が大部分で, これら 2 つの食品群を合わせると約 $50 \%$ を占めていた。含硫アミノ酸は，穀類から $30 \%$ ，魚介類から $20 \%$ 摂取してお り，全体からみると動物性食品からの摂取がわずかに上回った。スレオニンについては殼類と魚介類からがほ ぼ同率で，捖取割合が最も多かったが，全体からみるとやはり動物性食品からの摂取がやや多かった。しかし， 芳香族アミノ酸, トリプトファン, バリンについては, 動物性食品よりも植物性食品からの摂取が多く（52〜 $56 \%)$ ，乙かも植物性食品の中では穀類からの摂取が多かった（24〜30\%)。 
表 5 食品群別アミノ酸摂取量

（昭和 57 年；全国平均；g/ 1 人 1 日）

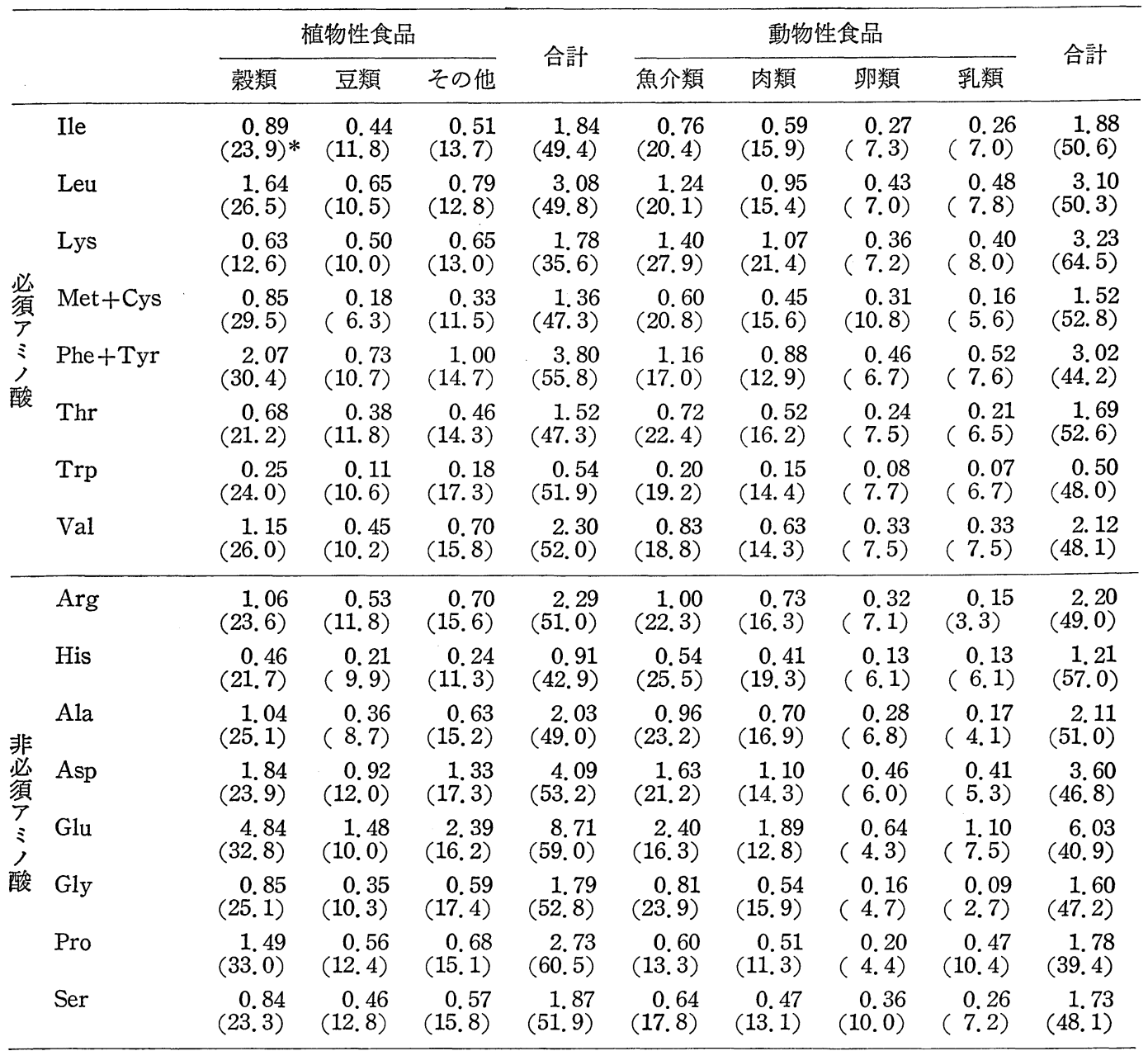

* : ( ) 内数字は各食品群からの摂取割合 (\%) を示す

また，非必須アミノ酸についても，ヒスチジンとアラニンを除いた他のアミノ酸は，動物性食品よりも植物 性食品からの摂取割合が高く，中でもプロリン $(61 \%)$ ，グルタミン酸（59\%）は高い割合を示した。これら 植物性食品からの摂取割合が高くなるにつれて，特に穀類からの摂取が増加することが，非必須アミノ酸にお いて特徵的であった。

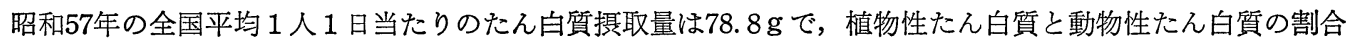
はほぼ半々（動たん比51\%）であった。これをさらに，表5のように食品群と，個々のアミノ酸摄取量との量 的関係を示すと，植物性食品と動物性食品からの摂取割合がかなり違うことが明らかにされた。

\section{要 約}

日本人の摂取たん白質の栄養評価を検討する目的で，国民栄養調査をもとに昭和 48 年から 57 年むでの過去 10 年間のアミノ酸摂取量およびアミノ酸スコアを算出した。むた，食品群別のアミノ酸摂取量について，昭和57 年のみを検討した。 
1）昭和48年から57年までの全国平均 1 人 1 日当たりのアミノ酸摂取量は, $77.4 〜 81.6 \mathrm{~g}$ の範囲にあり，各 年次による差はわずかであった。るた，全アミノ酸中の全必須アミノ酸割合 (EA\%) は，42.5〜 42.7\%で捸 取たん白質の栄養価は概悋良好でめった。

2）アミノ酸スコアは，この10年間 98 か 100 の間にあり，日本人の食事たん白質は化学価からも極めて良 好であることが裏づけられた。

3）昭和57年のたん白質摂取量における動たん比は $50.9 \%$ あっっだ，食品群別アミノ酸摂取量からみると， 個々のアミノ酸レベルでは動物性食品よりも植物性食品からの摂取割合が高いアミノ酸があり, それらは穀類 に由来する場合が多かった。

終わりに，有益な助言をいただいた放送大学 宮崎基嘉教授（前国立栄養研究所基礎栄養部長）なならびに国 立栄養研究所基礎栄養部 真田宏夫室長に深謝する。

本研究の一部は第30回日本栄養改善学会（昭和58年10月, 長野市) で発表した。

文献

1）松野信郎：栄養学雑誌，33，311 (1975)

2）松野信郎：栄養学雑誌，34，215 (1976)

3）松野信郎, 野村美弥, 宮崎基嘉 : 栄養学雑誌, 36, 261 (1978)

4) 細谷憲政編著：病態栄養学双書, 糖尿病, p. 89 (1972) 第一出版

5） Pösö, A.R., Wert, J. J., Jr and Mortimore, G.E. : J. Biol. Chem., 257, 12114 (1982)

6）厚生省公衆衛生局栄養課編：国民栄盖の現状，昭和48～57年（1976～1984）第一出版

7）科学技術庁資源調査会：四訂日本食品標準成分表（1982）大藏省印刷局

8）科学技術庁資源局：日本食品アミノ酸組成表（1966）大蔵省印刷局

9) $\mathrm{FAO} / \mathrm{WHO}$ : Report of a Joint $\mathrm{FAO} / \mathrm{WHO}$ Ad. Hoc. Expert Committee "Energy and Protein Requirements", p. 63 (1973) Geneva

10） Scrimshaw, N.S. : FAO/WHO/UNU 合同專門委員会提案, 「新しいエネルギー・蛋白質必要量につ いて」(講演) (1982) 東京

11）岩谷昌子，宮崎基嘉：第30回日本栄養改善学会講演集，p. 214 (1983）長野

12）厚生省公衆衛生局栄養課編：昭和54年改定 日本人の栄養所要量, p. 83 (1979) 第一出版

13）松野信郎, 山口迪夫, 野村美弥：栄養学雑誌, 36, 195 (1978)

（受付 : 昭和59年 8 月 8 日） 